[Beals, F. (2008). Conflicting Demands: Reviewing the Impact of Youth Policies on New Zealand Schools. New Zealand Annual Review of Education, 17, 91-105]

\section{Conflicting Demands: Reviewing the Impact of Youth Policies on New Zealand Schools}

\section{FIONA BEALS}

\section{Abstract:}

Government policies are often developed outside of the Ministry of Education, but with education and schooling in mind. This article will look at two such policies: the Youth Development Strategy Aotearoa (YDSA) and the Youth Offending Strategy (YOS). It will explore the contradictory ways in which the purpose and role of schooling are constructed within these policies and the resulting conflicting expectations placed on the compulsory schooling system. These expectations reflect classical notions of the functions of education. The challenge is to redevelop schooling "as we know it" by incorporating a key strength of the YDSA - that of authentic youth participation.

W hat counts as education in compulsory schooling is highly contested. In New Zealand, schools have to balance the competing demands from many interest groups, including differing public stakeholder groups and government ministries. Education is not only in the interests of the child but in the interests of society as a whole. For this reason, the public school is often seen as the battleground for social problems and ills. This was clearly apparent in the election year of 2002. Not only was 2002 a year in which party candidates debated social issues, released education policies, and argued about what schools should be doing, but 2002 was a year in which several extraordinary youth crimes featured in the courts, hitting news headlines and stirring a moral panic amongst the general public. In turn, media reporters, politicians and social commentators argued that schooling and education were a logical solution to a lost generation. Indeed, the cases of youth crime reported in 2002 suggested that schools were not just places in which teachers taught a curriculum and young people learned, but schools were also places in which young criminals could be identified and deterred from a life of crime. For media commentators, politicians, and the general public, schools became a major part of the solution to criminal deviance.

Amongst the turmoil of 2002, whilst the Ministry of Education concentrated on a curriculum stock-take, other Ministries released policies aiming at young people including the compulsory schooling system of New Zealand as a key component. Two such policies were the Youth Development Strategy Aotearoa (YDSA) (Ministry of Youth Affairs, 2002) and the Youth Offending Strategy (YOS) (Ministry of Justice \& Ministry of Social Development, 2002). Whilst the YOS was directed at the criminal minority of youth (such as those making headline news), the YDSA was focused on the mainstream of young people - those young people engaged in society and education.

Hence, the YDSA and YOS were written with two very different groups of youth in mind, and, as such, the way schooling was constructed in each policy differed. In this article, I will explore these policies and the ways in which the role and purpose of education were explicitly conceptualised in each. I will argue that, in effect, these policies reconstruct and replay deep tensions in the philosophical argument for education. Finally, I attempt to provide some resolution to this argument by drawing upon notions of authentic youth participation - a key element of the YDSA.

\section{The Youth Development Strategy Aotearoa}

The YDSA was released by the Ministry of Youth Affairs (now the Ministry of Youth Development) in 2002 as a cornerstone and guiding policy for young people between the ages of 12 and 25 years of age. The Ministry intended the YDSA to be an overarching policy for other Ministries and youth-focused agencies such as the Ministry of Education and public schools. In the Strategy document, the Ministry of Youth Affairs encouraged various agencies in the youth sector to celebrate youth, to involve youth, and to include youth in any decision making. To this end, the Ministry also consulted widely in the development of the Strategy. A total of 1450 young people were involved in reference groups, with the majority of these groups being held through secondary schools across New Zealand (Ministry of Youth Affairs, 2002). In addition to this, focus groups were held throughout New Zealand with organisations working with youth and stakeholders in the youth sector. 
Despite the large involvement of youth and stakeholder groups, very few education practitioners were involved in the initial development. It was not until 2001 (a year before the release of the Strategy) that a principal joined the main advisory group; alongside this, only one focus group was held with secondary and tertiary educators (in Whangarei) and only nine out of 160 written submissions came from secondary and tertiary providers (Ministry of Youth Affairs, 2002). Hence, although secondary students were included in the development of the Strategy, it seems that the response, or even the inclusion, of adults in the education sector was insignificant in comparison. This is despite the intention of the Strategy to be "applied within local government, workplaces, schools, youth and community organisations" (Harré, 2002, p. 4).

Within the Strategy, the Ministry of Youth Affairs (2002) is outcome-focused in more ways than those relating to the physical, emotional, and psychological wellbeing of young people in New Zealand society. Indeed, throughout the Strategy, the Ministry makes it clear that the healthy development of young people is "an economic essential" (p. 10) for New Zealand. With neo-liberal reference to New Zealand as an economy, rather than a society, the authors of the Strategy note that reduced health and justice costs (the effects of negative development) lead to increased involvement in the labour force. Young people themselves are seen as active goal-directed subjects needing to develop skills to fully participate and succeed in a knowledge economy. This involves a particular view of development which encourages, rather than discourages, the involvement of young people.

The Strategy itself is an attempt to move beyond deficit views of young people and youth development to seeing young people as valuable members of the community who, if supported positively, can contribute to both their own development and the development of the community. In effect, the Strategy is an attempt of the then Ministry of Youth Affairs to incorporate a "fresh" and currently popular view of human development. The focus of investigation is not pathology or risk but a strengths-based picture, which enables a broader understanding of the young person in context and, ideally, does not define the young person as "the problem" (Ministry of Youth Affairs, 2002, p. 20).

Whether the Strategy actually achieves this is questionable as a deficit/risk view of youth issues is drawn upon extensively in both the Strategy and the literature review published to accompany it (McLaren,
2002). This conceptual problem alone is not inherent only to the YDSA, but is a key problem of strengths-based approaches which continue to draw upon developmental psychology; a type of knowledge that is often focused on separating the normal from the abnormal through an emphasis on pathology (Foucault, 1965; Rose, 1990, 1996). In effect, the authors of the Strategy, like other strengths-based approaches, want to use ideas such as resilience and protective factors (key components of a strengths-based approach) without referring to risk factors - an impossibility, as resilience and protective factors are defined through an idea of an absence of, or a reaction to, risk and pathology.

Aside from the problems in development and conceptualisation of the Strategy, the authors of the Strategy argue throughout that schools and education play an important role in the positive development of young people (McLaren, 2002; Ministry of Youth Affairs, 2002). Schools are seen as key institutions in the development of young people and, as such, it is argued that schools need to be strongly connected to the other contexts in a young person's life (the family and the community). A positive experience in school is seen as a key protective factor in the young person's life which can be used to counter the existence of risk factors. In particular, teachers are seen in the Strategy as key players in the development of young people, and both the Strategy and literature review note that a good teacher can make a big difference in the lives of young people.

As a result, the authors of the Strategy highlight several recommendations addressed to the administration, management, and curriculum of New Zealand schools, which they place directly alongside the Ministry of Education's (1999) Health and Physical Education in the New Zealand Curriculum. The key aim of the Ministry of Youth Affairs is that schools should incorporate a strengths-based approach in teaching which involves connections to the family and community, and includes young people themselves. A key concern articulated in the YDSA is that the experiences in school for a minority group of young people are quite negative and, in turn, these experiences influence their development adversely. In the literature review for the Strategy, Kaye McLaren (2002) notes that practices in education, such as actively identifying at-risk students and streaming, can unintentionally exclude particular groups of young people from "quality" teaching and educational opportunities. In effect, the Ministry of Youth Affairs attempts, through the Strategy, to challenge schools to move beyond "deficit" approaches, in which students are viewed as "problems", to a stance which challenges the 
ways in which the schooling experience may be viewed as problematic for particular groups of young people.

A key method proposed in the YDSA for developing a strengthsbased approach is authentic youth participation. That is, the Ministry of Youth Affairs (2002) throughout the Strategy argues that it is possible to "trigger" (p. 8) healthy development by including young people in decisions and activities:

We can contribute to young people's healthy development by creating opportunities for them to influence, solve problems, inform, shape, design and contribute to an activity or idea. Effective participation can lead to more "ownership" of the activity/idea and help ensure that policies, services and programmes meet young people's needs. (Ministry of Youth Affairs, 2002, p. 23)

The key to this form of participation is the idea that effective participation is "more than just consulting young people" (Ministry of Youth Affairs, 2002, p. 25); it is the full involvement of young people "in developing, evaluating, and reviewing decisions that affect them" (p. 25). Throughout the Strategy, schools are seen as key environments which can potentially foster this form of participation. In particular, schools are encouraged to involve students in most of the key decision-making occurring in the school whilst encouraging and supporting student-led initiatives and ideas. This is later developed by the Ministry of Youth Development (2005) in an education-based policy resource for the YDSA Making it Happen, which gives several examples of student involvement in most, if not all, stages of decision making.

Authentic youth participation is a key strength of the YDSA. Goals of participation ideally involve organisations, such as schools, in challenging current ways of thinking about young people (such as the type of thinking around a pparent deficit approaches). In effect, the then Ministry of Youth Affairs (2002) is arguing that participation triggers healthy development - not only does it involve the young person in "taking some responsibility" but it involves organisations in rethinking the ways in which they view young people. However, as an ideal, authentic participation is seldom authentic for all groups of young people. Often particular groups of youth are seen as being able to participate better than others (Nairn, Sligo, \& Freeman, 2007). In particular, as Nairn and colleagues found in local government decision making in New Zealand, two particular groups of young people are usually included in participatory approaches (and each of these groups participates very differently) - those high-achieving youth who are typically seen as highly capable of participation, and those "at-risk" youth who are seen as needing some form of control. Nairn and colleagues define the group of young people left out as the "excluded middle" (p. 249). Often, perhaps without realising it, organisations attempting to provide opportunities for participation focus on those young people already capable of participation, without providing opportunities for all youth to develop this capability.

Indeed, by looking at how youth participation is defined in another 2002 policy, the Youth Offending Strategy (Ministry of Justice \& Ministry of Social Development, 2002), it is apparent that participation means something very different in the youth justice sector. Whilst the YDSA frames participation in a positive light that ideally sees young people actively participating in society and contributing to their community, the YOS defines participation as providing young people with "every opportunity to fully participate in the youth justice system" (Ministry of Justice \& Ministry of Social Development, 2002, p. 6). Its rather different aim is to encourage the young person to take responsibility for his/her actions and to assist practitioners in directing an "appropriate response" (p. 6) at the deviant young person.

\section{The Youth Offending Strategy}

Whilst the intention behind the YDSA is to celebrate youth, the intention behind the YOS is to intervene in the behaviour of a minority group of problematic "at-risk" youth. Within both the strategies, the authoring Ministries (Ministry of Youth Affairs for the YDSA and Ministry of Justice \& Ministry of Social Development for the YOS) refer to developmental psychology and education to frame a picture of today's youth and the purposes of their education. However, the way in which young people and education are framed within both strategies is very different.

Within the first few pages of the YOS, readers are informed that the Strategy works alongside the YDSA as a tool to work with young people, and the authors argue for the "promotion of the youth development approach, as outlined in the Youth Development Strategy Aotearoa" (Ministry of Justice \& Ministry of Social Development, 2002, p. 31). It would be logical to assume that readers would be encouraged to take a strengths-based approach to youth justice, which would move beyond seeingyoung people as "risks" and "problems" to be controlled. In reality, readers of the YOS are confronted with a very different 
developmental picture of young people. The Strategy itself is saturated with a language of risk and pathology. Practitioners within the youth justice sector are encouraged to identify problematic children as early as possible, track their pathways, and directly intervene in their lives. Whereas the readers of the YDSA are encouraged to identify and build from the resources within the young person, readers of the YOS are encouraged to change the young person and the problematic family environment in which they live.

To put it simply, the YOS explicitly encourages the use of a deficit approach, in which young persons and their immediate family are viewed as the problem. Furthermore, these young people are often already marginalised in society by reason of gender, ethnic, and socio-economic divisions. Rather than being invited to address any inequalities, readers of the YOS are encouraged to see the need to change the young person to fit into society through promoting "healthy development and socialisation" (Ministry of Justice \& Ministry of Social Development, 2002, p. 26). In line with Bishop's (2003) observation on deficit thinking in education (because young people are directly seen as the problem), the solution advocated is that the young person needs to change and become more like the "normal" white middle-class youth.

Another contrast to the YDSA is the way in which identification of problem youth is articulated within the YOS. In contrast to the problematic reasoning behind identifying and streaming found in the YDSA, readers of the YOS are encouraged to view "streaming" of young people into risk-factor groups as an effective and appropriate means of identifying and working with young people. The authors of the YOS acknowledge that some debate exists around grouping young people into risk groups, but then argue that streaming is already happening so it might as well be formalised in some form or another.

In effect, the argument exists in the YOS that, if young people are streamed into groups, then interventions can be targeted at them which should produce the greatest change. Whether this is an effective argument is debatable. Researchers such as White (2002) and Priday (2006) argue that often the risk factors used to stream offenders into risk groups are socially distributed, reflective of social inequalities, and not objective measures of an individual's risk. That is, through "streaming", particular marginalised groups (such as lower socio-economic and minority ethnic groups) are likely to be singled out as risks, and are defined as the problem, when the problem could actually be a larger reflection of society itself.
Alongside streaming, early intervention is also singled out within the YOS as a key tool for crime reduction. Early intervention is the identification of problem individuals at the earliest point possible and then the directing of resources to them and their family. It is at this point that schooling and education are seen as key points for intervention (Hema, 2000, 2001; Ministerial Taskforce on Youth Offending, 2002). Resulting from this, the Taskforce makes several recommendations specifically directed at the education sector: schools are first identified as sites for early identification and intervention; secondly, schools are encouraged to focus on "lifting" the outcomes of Maori and Pacific youth; and finally, the education sector as a whole is asked to enforce a system to track the attendance of young people at schools. In effect, the YOS recognises that schools can be both a risk factor to criminal deviance and a point of intervention (cf. McLaren, 2000) and, returning to the goals of the YDSA, the YOS focuses on schools as sites where the citizens of tomorrow could be developed. For the YOS, this would occur through classroom management and pedagogical practices that would reinforce the function and role of education - that of socialisation and social control (cf. McLaren, 2000).

\section{The Functions of Education, the YDSA and YOS}

Within both the YDSA and YOS, education is given a particular role in the way it approaches schooling for young disaffected youth (referred to in the YOS as youth-at-risk). In the YDSA, readers are alerted to the importance of a quality relationship between the teacher and the student which, in turn, nurtures the developing youth. In contrast, the type of relationship espoused in the YOS is one of supervision and control. Furthermore, a closer reading of both documents reflects a deeper tension and incompatibility concerning the reasons for schooling and mass education.

Kerrin Egan (1983, 1992, 1999, 2001) argues that contemporary schooling and mass education attempts to accomplish three goals: individualisation, socialisation, and the learning of truth. Whilst neither the YDSA nor the YOS address the type of knowledge being taught, both strategies construct the direct function of schools as developing productive adults who would later contribute positively to New Zealand as a society and an economy. The YDSA and YOS are also explicitly polarised on whether education should develop individuals or should socialise children into a social "sameness". In the YOS, the reader is drawn to a focus on socialisation whilst, in the YDSA, the 
reader is encouraged to celebrate difference and nurture the development of the individual. Whilst it is possible to argue that such a nurturing relationship could, in an indirect way, socialise the child (Walkerdine, 1998), the way this relationship is portrayed in both strategies differs significantly. In the YDSA, the reader is presented with a relationship of compassion; whilst in the YOS, the relationship is one of control.

The explicit focus on education in the YOS acknowledges the socialisation function of mass education. Socialisation is a reality of education. In the context of the YOS, however, it is not only a reality but a necessity for potentially deviant young people. In the context of the YOS, socialisation is the key focus of the educational experience for the youth-at-risk as young people are constructed throughout the Strategy as problematic individuals who need transformation. Egan $(1983,2001)$ argues that such a focus effectively enforces differences within a society in an attempt to reproduce the values and norms of a society. That is, in an attempt to socialise, or assimilate, problematic groups, there is a focus on what creates the difference in the first place. In response, young people who are different from the mainstream are singled out, focused on, and transformed to become like the mainstream. In a sense, socialisation becomes an oxymoron as, in order to socialise, one must first enforce difference. Through a focus on "objective" risk factors in the YOS, practitioners are encouraged to engage in such practices that enforce difference - differences based on gender, socio-economic, and ethnicity factors.

In contrast, readers of the YDSA are encouraged to celebrate diversity in "facilitating the development of students' potential" (Ministry of Youth Affairs, 2002, p. 23). In effect, educational practitioners are encouraged to nurture the individual within the student. In such a context, education is about explicitly bringing out the distinct differences within individuals (Egan, 2001). Unfortunately, although individualism can be an educational ideal, the reality is that it may not happen for all students, if (as in the case of the YOS), problematic groups are excluded from such an educational experience and are targeted in techniques of socialisation. Furthermore, in an education system that focuses on individualisation alone, there is a risk of fragmenting society to such an extent that it is difficult to conceive of a coherent whole.

Egan argues that individualisation and socialisation are incompatible ideas (2001). Both attempt to address the problem within the other but never offer any solution. He argues that we need to move away from arguments for socialisation and individualisation and begin to conceptualise education as a process through which one acquires intellectual tools (1999). For Egan (1992), education is about the fostering of imagination which in turn leads to social transformation. Particularly within the YDSA, there is a possibility for this kind of educational experience, not through individualisation but through authentic participation. Within this, the question is: how do we enrich the educational experiences of all students, whilst celebrating diversity and acknowledging difference without falling into an us and them trap which excludes some groups of students? What is needed is a model of authentic participation for education.

\section{Authentic Participatory Education}

Authentic participation counters both individualisation and socialisation. It is not about making individuals but bringing diverse groups of individuals together; it is not about moulding citizens but involving young people as active subjects in the learning process, not passive pieces of clay. It is also more than the presentation of a set curriculum reflecting a socially determined truth because it involves young people in establishing the curriculum alongside teaching staff. Authentic participation in education is:

[a] way to redefining power relations in the classroom and to challenging the idea that important knowledge is only that named and endorsed by academicians and bureaucrats outside the classroom. (Beane, 1997, p. xi, italics added)

In a context of tokenistic participation, young people might be consulted on particular matters related to their learning, but the process finishes at that point and the decisions are left to the adults "who know best". In order to be authentic, participation needs to give some form of responsibility to young people. It is this addition of responsibility which makes participation more than just tokenistic. However, providing young people with some responsibility is not enough; it is also important that young people have the means to achieve (Epstein, 2007). This is especially important for the "excluded middle" and disaffected groups of youth who are often viewed as failures when they fail to finish a task when, in reality, they were not given the tools needed for successful completion. Hence, in the context of the classroom, young 
people need to be given opportunities to take responsibility, and the resources needed to perform under that responsibility.

It is also possible to pose the same argument in the opposite direction. If educators, at any point, are required to give opportunities of participation to their students, then the educators themselves need the resources to work alongside and with students. Fortunately, there is already a tool in the theoretical toolkit that teachers can draw upon to enable authentic participation. James Beane (1997) calls this the "integrated curriculum" (p. xi) whilst others, such as Ira Shor (1992, 1996) draw upon the work of Paulo Freire to define this form of education as a "critical pedagogy". To both Beane and Shor, education needs to be a participatory experience in which both the student and teacher work together at posing problems and redefining the world. An integrated curriculum or critical pedagogy effectively brings together the teacher and students in problem posing and solving; it is about "performing knowledge" (Beane, 1997, p. xi) in such a way that the students and teachers transform their understanding of themselves and the world in which they live.

Beane (1997) argues that providing an integrated structure to teaching and learning "... is not simply about doing things differently, but about doing something really different" (p. xi). In an integrated curriculum or critical pedagogy, the teacher and students bring together their personal lived experiences, relevant social issues, and knowledge in a way that enables the investigation and understanding of different viewpoints and perspectives. This can only be achieved if the learning starts with the questions and concerns students have about themselves and their worlds.

Through an integrated curriculum model, education is redefined from an enterprise in which the students are caught in a binary between individualisation and socialisation to one in which the imagination is "set on fire" to think in different ways - ways that lead to social transformation. In this process, the teacher works as a facilitator of dialogue as well as a teacher of tools as s/he builds with students the resources needed for their learning and dialogue.

An approach to teaching from the perspectives of critical pedagogy and integrated curriculum may be an idealised dream for education today in contemporary New Zealand. However, there are really only two challenges to this approach to teaching - the first is pragmatic and somewhat simply eliminated and the second can be seen as a professional problem. Pragmatically, schools in New Zealand are required to follow a national curriculum which involves them in teaching eight subject areas. It could be argued that there is no room for an integrated and critical approach to learning. However, in the latest curriculum statement (Ministry of Education, 2007) the Ministry notes that an "effective pedagogy" involves reflective thought and action, shared learning, connections to prior experience and inquiry. It is too early to tell now but, perhaps, there will be more flexibility and opportunity for authentic participation in the new curriculum. Only time will tell.

The second, professional challenge concerns the role of the teacher, as any approach involving authentic participation impacts and transforms professional identity as a "teacher" (Bragg, 2007). This is especially apparent when a critical pedagogy/integrated curriculum approach moves education away from a progressive model of education, where the teacher guides the class, to a transformative model where the teacher and class reconstruct understanding. Any scepticism teachers may have towards authentic participation may be reflective of an anxiety that young people lack the ability to participate effectively. The real challenge here is the need to take a risk and provide students with both the opportunity and the resources to participate. Authentic participation is not about throwing young people into the "deep end", or about selecting a group of "ready and able" students, but about gradually introducing young people to participation.

\section{Conclusion}

It is often possible to examine the old ideas of education in a fresh light by looking at the ways in which education is talked about - not just in the education sector but in other social sectors. In this article, I have examined two policies concerning young people, and constructed an idea of education. Both these policies draw upon old ideas about the purpose of education, and within one of these policies, the YDSA, it is possible to see an alternative view of education. This view also reflects an old idea of transformative critical pedagogy, but is given a new life in an idea of authentic youth participation. Authentic youth participation enables students and teachers to work together on current issues and topics leading to a transformative dialogue. 


\section{References}

Beane, J. A. (1997). Curriculum integration: Designing the core of democratic education. New York: Teachers College Press.

Bishop, R. (2003). Changing power relations in education: Kaupapa Maori messages for "mainstream" education in Aotearoa New Zealand. Comparative Education, 39(2), 221-238

Bragg, S. (2007). "But I listen to children anyway!" - Teacher perspectives on pupil voice. Educational Action Research, 15(4), 505-518.

Egan, K. (1983). Educating and socializing: A proper distinction? Teachers College Record, 85(1), 27-42.

Egan, K. (1992). The roles of schools: The place of education. Teachers College Record, 93(4), 641-655.

Egan, K. (1999). Education's three old ideas, and a better idea. Journal of Curriculum Studies, 31(3), 257-267.

Egan, K. (2001). Why education is so difficult and contentious. Teachers College Record, 103(6), 923-941.

Epstein, R. (2007). The case against adolescence: Rediscovering the adult in every teen. Sanger, California: Quill Driver Books.

Foucault, M. (1965). Madness and civilization: A history of insanity in the age of reason (R. Howard, Trans.). London: Routledge.

Harré, L. (2002). Foreword from the Minister of Youth Affairs. In Ministry of Youth Affairs (Ed.), Youth Development Strategy Aotearoa: Action for child and youth development (pp. 4-5). Wellington: Ministry of Youth Affairs. Retrieved from $<$ www.myd.govt.nz/media/pdf/ydsa_doc_final.pdf $>$.

Hema, L. (2000). Risk and strength factors for children and young people who offend or reoffend: A summary of the literature. Wellington: Department of Child, Youth and Family Services.

Hema, L. (2001). Report to the Ministerial Taskforce on Youth Offending on serious recidivist offenders. Wellington: Department of Child, Youth and Family Services.

McLaren, K. L. (2000). Tough is not enough: Getting smart about youth crime - a review of research on what works to reduce offending by young people (Report). Wellington: Ministry of Youth Affairs. Retrieved from $<$ www.myd.govt.nz/media/pdf/tough_is_not_enough(fulldoc).pdf>.
McLaren, K. L. (2002). Youth development literature review: Building strength: A review of research on how to achieve good outcomes for young people in their families, peer groups, schools, careers and communities (Report). Wellington: Ministry of Youth Affairs. Retrieved from $<$ www.myd.govt.nz/media/pdf/YDSA\%20Lit\%20Review.pdf>.

Ministerial Taskforce on Youth Offending. (2002). Report of the Ministerial Taskforce on Youth Offending (Ministerial Report). Wellington: Ministry of Justice, Ministry of Social Development. Retrieved from

$<$ www.justice.govt.nz/pubs/reports/2002/youth-offending-strategy/ ministerial-report/youth-ministerial-taskforce.pdf $>$.

Ministry of Education. (1999). Health and physical education in the New Zealand curriculum. Wellington: Learning Media.

Ministry of Education. (2007). The New Zealand curriculum. Wellington: Learning Media. Retrieved from

$<$ http://nzcurriculum.tki.org.nz/content/download/866/6081/file/ Curr\%20-TEXT.pdf>.

Ministry of Justice, \& Ministry of Social Development. (2002). Youth Offending Strategy. Wellington: Ministry of Justice, Ministry of Social Development. Retrieved from

$<$ www.justice.govt.nz/pubs/reports/2002/youth-offending-strategy/ youth-strategy/youth-strategy.pdf $>$.

Ministry of Youth Affairs. (2002). Youth Development Strategy Aotearoa: Action for child and youth development (No. 0-478-25004-5). Wellington: Ministry of Youth Affairs. Retrieved from

$<$ www.myd.govt.nz/media/pdf/ydsa_doc_final.pdf $>$.

Ministry of Youth Development. (2005). Making it happen... Strengthening youth development in schools. Wellington: Ministry of Youth Development. Retrieved from $<$ www.myd.govt.nz/uploads/docs/00.7.6.7makingithappen.pdf >.

Nairn, K., Sligo, J., \& Freeman, C. (2007). Polarizing participation in local government: Which young people are included and excluded? [Electronic Version]. Children, Youth and Environments, 17, 248-271. Retrieved October 15, 2007, from <www.colorado.edu/journels/cye $>$.

Priday, E. (2006). Thinking about new directions in juvenile justice: Risk and cognitive behaviourism. Current Issues in Criminal Justice, 17(3), 413-430. 
Rose, N. (1990). Governing the soul: The shaping of the private self. London: Routledge.

Rose, N. (1996). Inventing our selves: Psychology, power and personhood. Cambridge: Cambridge University Press.

Shor, I. (1992). Empowering education: Critical teaching for social change. Chicago: University of Chicago Press.

Shor, I. (1996). When students have power: Negotiating authority in a critical pedagogy. Chicago: University of Chicago Press.

Walkerdine, V. (1998). Developmental psychology and child-centred pedagogy: The insertion of Piaget into early education. In J. Henriques, W. Hollway, C. Urwin, C. Venn, \& V. Walkerdine (Eds.), Changing the subject: Psychology, social regulation and subjectivity (pp. 153-202). London: Routledge.

White, R. (2002). Pros and cons of early intervention. Youth Studies Australia, 21(4), 16-23.

\section{The author}

Dr Fiona Beals is a lecturer in the Faculty of Education at Victoria University of Wellington. She has an interest in educational sociology and critical youth studies. Fiona has recently completed her doctoral study in which she explored the ways in which the media, government, and academia constructed discourse around youth crime in the 2002

election year. 